\title{
IMPLEMENTASI ALGORITMA BEST FIRST SEARCH DALAM SISTEM PAKAR PERTOLONGAN PERTAMA PADA BAYI DAN ANAK
}

\author{
Husni Angriani ${ }^{1}$, Yeni Saharaeni ${ }^{2}$ \\ Sistem Informasi, STMIK KHARISMA Makassar ${ }^{1}$ \\ Manajemen Informatika, STMIK KHARISMA Makassar ${ }^{2}$ \\ Email : husniangriani@kharisma.ac.id ${ }^{1}$,yenisaharaeni@kharisma.ac.id²
}

\begin{abstract}
ABSTRAK
Alternatif yang biasanya dilakukan orang tua ketika anak atau bayi sedang sakit adalah mencari informasi melalui internet. Namun beberapa website masih bersifat pasif sehingga orang tua tidak dapat melalukan penanganan dengan tepat. Sistem Pakar dapat membantu orang tua dalam menangani atau memberikan panduan bagi orang tua ketika anak atau bayi sedang sakit atau mengalami gejala yang tidak biasanya. Untuk mendukung pencarian solusi dari sistem pakar maka dibutuhkan algoritma best first search. Algoritma ini dinilai sangat efektif dalam pencarian solusi dalam node berdasarkan pola penalaran yang digunakan. Hasil dari implementasi algoritma best first search dapat membantu menemukan solusi yang tepat dari permasalahan berdasarkan gejala yang dialami. Pencarian solusi membutuhkan waktu yang cukup lama, namun solusi yang diberikan merupakan solusi terbaik untuk permasalahan tersebut.
\end{abstract}

Kata Kunci: Best first search, sistem pakar, pertolongan pertama.

\begin{abstract}
An alternative that parents usually do when a child or baby is sick is to find the information via internet. However, some websites are still passive, so the parents cannot handle them properly. The Expert System can assist the parents in managing or providing guidance for them when their child or baby is sick or experiencing unusual symptoms. To support the searching solution by the expert systems, a best first search algorithm is needed. The algorithm is considered more effective in finding solutions in nodes based on the reasoning patterns used. The results of the implementation of the best first search algorithm can help to find the right solution for the problem based on the symptoms experienced. Finding a solution takes a long time, but the solution that has given is the best solution for this problem.
\end{abstract}

Keywords: Best first search, Expert system, first aid.

\section{PENDAHULUAN}

Ketika bayi atau anak sedang sakit atau mengalami gejala yang tidak seperti biasanya, Salah satu alternatif yang dilakukan orangtua untuk menangani masalah tersebut adalah dengan mencari informasi melalui internet. Namun pada beberapa website, informasi yang ditampilkan masih bersifat pasif sehingga penanganan yang dilakukan orang tua biasanya kurang tepat. Sistem pakar dapat digunakan untuk mengantisipasi hal 
tersebut, karena pakar memiliki solusi dari suatu permasalahan yang tidak dapat dipecahkan oleh orang lain secara efisien (Supartini \& Hindarto, 2016).

Untuk mendukung pola penalaran dalam sistem pakar, digunakan algoritma best first search dalam melakukan panduan pencarian ke arah node yang tepat dimana solusi dari masalah berada. Pendekatan yang dilakukan yaitu pencarian solusi terbaik berdasarkan pengetahuan yang dimiliki sehingga penelusuran yang dilakukan dapat ditentukan mulai dari mana dan bagaimana menggunakan proses terbaik untuk pencarian solusi.

Penerapan Algoritma Best first search dalam Sistem Pakar pertolongan pertama pada bayi dan anak diharapkan dapat membantu proses pencarian solusi terbaik untuk setiap permasalahan dalam mendukung pola penalaran pada sistem pakar.

\section{LANDASAN TEORI}

Proses pencarian merupakan penelurusan solusi dalam suatu permasalahan hingga solusi atau tujuan ditemukan, atau pergerakan dari statespace untuk mencari lintasan dari initial-state ke goal-state (Harvei, 2018).

Cara kerja dari Metode Best First Search yaitu dengan membangkitkan node berikutnya dari sebuah node terbaik diantara semua leaf nodes (simpul-simpul pada level terdalam) yang sebelumnya pernah dibangkitkan (Rian, Tedy \& dwi, 2018). Metode tersebut juga memperbolehkan pencarian ke arah node yang lebih rendah jika node tersebut memiliki nilai heuristik yang lebih baik (santi, 2015). Best-First Search (BFS) merupakan kombinasi dari kelebihan metode Depth First dan Breath First Search. Penggabungan dua teknik search ini digunakan untuk menelusuri satu jalur pada satu waktu, tetapi dapat berpindah pada saat jalur lain terlihat lebih baik dari jalur yang sedang ditelusuri. Pada setiap state yang dihasilkan dengan fungsi heuristik diberikan skala prioritas untuk memperoleh jalur terbaik (Desaga, sujito \& Ali, 2017).

\section{METODE PENELITIAN}

Dalam mendukung pola penalaran pada sistem pakar, dibutuhkan penerapan algoritma best first search untuk pencarian solusi terbaik. Teknik best first search merupakan teknik yang menggunakan pengetahuan sebuah masalah dalam melakukan penelusuran yang menjadi panduan pencarian ke arah node solusi berada. Biasanya jenis ini disebut juga dengan heuristic (Khalid, Muhammad \& Haviz, 2020).

Untuk memperoleh data gejala, masalah dan solusi, maka dilakukan studi pustaka dan wawancara terhadap dokter anak dan beberapa tenaga medis yang berkaitan dengan penelitian ini. Secara Garis besar peneliti melakukan studi pustaka kemudian melakukan verifikasi dan validasi hasil studi tersebut melalui wawancara terhadap tenaga medis.

Hasil verifikasi tersebut kemudian diimplementasikan kedalam algoritma Best First Search untuk memudahkan sistem dalam melakukan pencarian solusi berdasarkan gejala dan permasalahan.

Langkah awal yang dilakukan untuk mengimplementasikan kedalam algoritma yaitu memberikan kode pada setiap gejala. 
Setelah pemberian kode, maka dibuatlah pohon keputusan. Pola pencarian solusi dibuat berdasarkan flowchart algoritma best first search pada Gambar 1.

Pada Gambar 1 diperlihatkan flowchart algoritma Best first search.

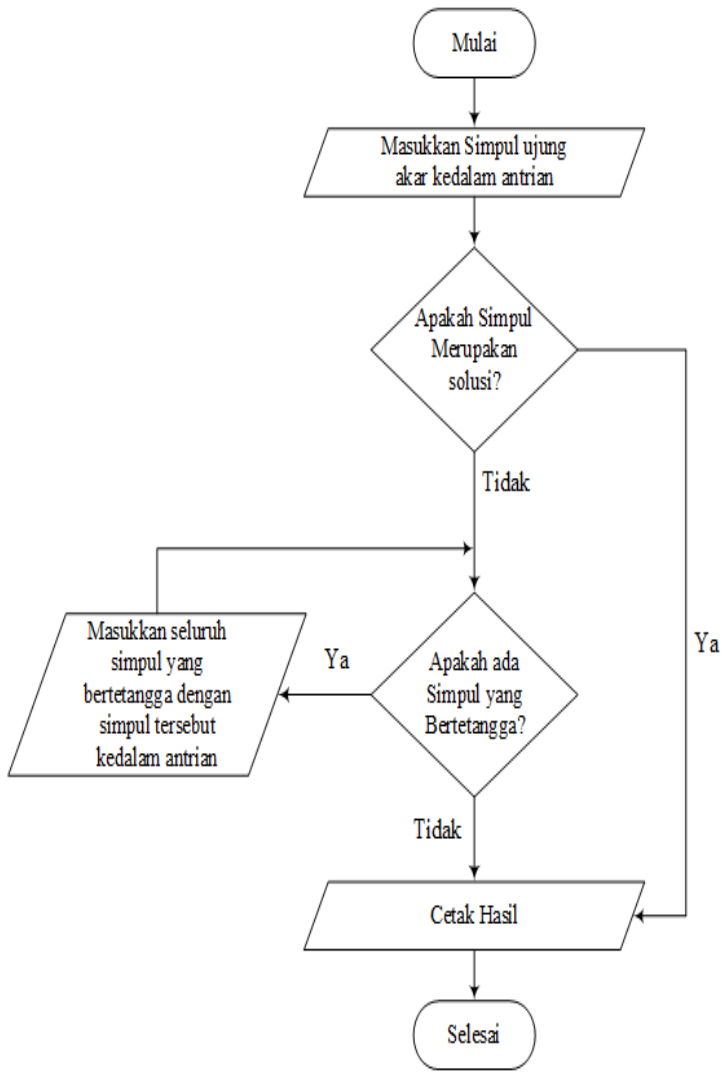

Gambar 1. Flowchart Algoritma Best first search

Proses pencarian solusi dimulai dengan memasukkan simpul / node ujung akar kedalam antrian, setelah itu di cek apakah node tersebut merupakan solusi atau bukan. Jika node tersebut merupakan solusi, maka solusi tersebut akan ditampilkan. Namun jika node tersebut bukanlah sebuah solusi maka akan di cek apakah ada node lain yang berada didekat node saat ini. Jika terdapat node lain yang berdekatan maka seluruh node tersebut dimasukkan kedalam antrian yang akan ditelusuri. Contoh dari algoritma best first search dapat dilihat pada Gambar 2.

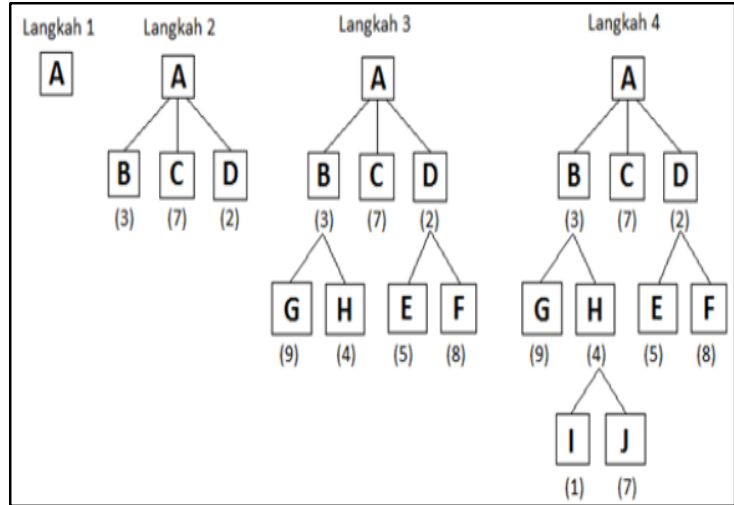

Gambar 2. Contoh Algoritma Best first search

\section{HASIL DAN PEMBAHASAN}

Implementasi Algoritma Best first search diterapkan pada proses pencarian solusi. Pada penelitian ini, terdapat 8 masalah kesehatan pada bayi dan 28 masalah kesehatan pada anak. Salah satu contoh penerapan algoritma best first search pada pencarian solusi masalah tidur bayi diperlihatkan pada Gambar 3 .

Sebelum proses pencarian solusi dibuat, maka terlebih dahulu dibuat pemetaan terhadap masalah dan gejala serta pemberian kode terhadap setiap gejala dan solusi untuk dijadikan sebagai node dalam proses pencarian solusi. Berikut ini contoh masalah dan gejala pada masalah bayi dan anak yang diperoleh melalui buku referensi yang diverifikasi oleh narasumber yaitu dokter anak dan tenaga kesehatan melalui wawancara.

Untuk Masalah Pola Tidur Bayi tidak menentu, memiliki gejala antara lain : Usia bayi diatas 4 bulan, durasi tidur bayi normal untuk bayi seusianya, Bayi lebih banyak tidur siang dari pada tidur malam hari, Bayi selalu mengikuti pola tidur siang lebih banyak dari malam hari. Untuk masalah Bayi tidur terlalu banyak tidur disiang hari, Gejalanya antara lain Usia 
bayi diatas 4 bulan, Durasi tidur bayi normal untuk bayi seusianya, Bayi lebih banyak tidur siang dari pada tidur malam hari, Pola tidur bayi selalu berubah dan Bayi terbiasa tidur siang. Beberapa Gejala berikut ini dapat mengindikasikan bahwa suara dapat menjadi masalah utama yang mengganggu tidur pada Bayi diantaranya : Usia bayi diatas 4 bulan, Durasi tidur bayi normal untuk bayi seusianya, Bayi lebih banyak tidur siang dari pada tidur malam hari, Pola tidur bayi selalu berubah, Bayi tidak terbiasa tidur siang dan Bayi tidur bersama orang tua (Smith \& Davidson, 2009).

Berdasarkan referensi yang telah diperoleh, maka untuk setiap gejala diberikan kode tertentu untuk memudahkan dalam pencarian solusi menggunakan algoritma best first search. Berikut ini kode yang diberikan untuk setiap gejala, pemberian kode berdasarkan cara kerja dari algoritma tersebut dalam menelusuri setiap node dalam mencari solusi seperti pada Gambar 3.

Masalah : Pola Tidur Bayi tidak menentu (1j)

Gejala :

- Usia bayi diatas 4 bulan (1)

- Durasi tidur bayi normal untuk bayi seusianya (1b)

- Bayi lebih banyak tidur siang dari pada tidur malam hari (1f)

- Bayi selalu mengikuti pola tidur siang lebih banyak dari malam hari (1h)

Masalah : Bayi tidur terlalu banyak tidur disiang hari $(1 \mathrm{n})$

Gejala :

- Usia bayi diatas 4 bulan (1)
- Durasi tidur bayi normal untuk bayi seusianya (1b)

- Bayi lebih banyak tidur siang dari pada tidur malam hari (1f)

- Pola tidur bayi selalu berubah (1h)

- Bayi terbiasa tidur siang (1k)

Masalah : Suasana malam atau suara mengganggu tidur bayi (11)

Gejala :

- Usia bayi diatas 4 bulan (1)

- Durasi tidur bayi normal untuk bayi seusianya (1b)

- Bayi lebih banyak tidur siang dari pada tidur malam hari (1f)

- Pola tidur bayi selalu berubah (1h)

- Bayi tidak terbiasa tidur siang (1k)

- Bayi tidur bersama orang tua (1i)

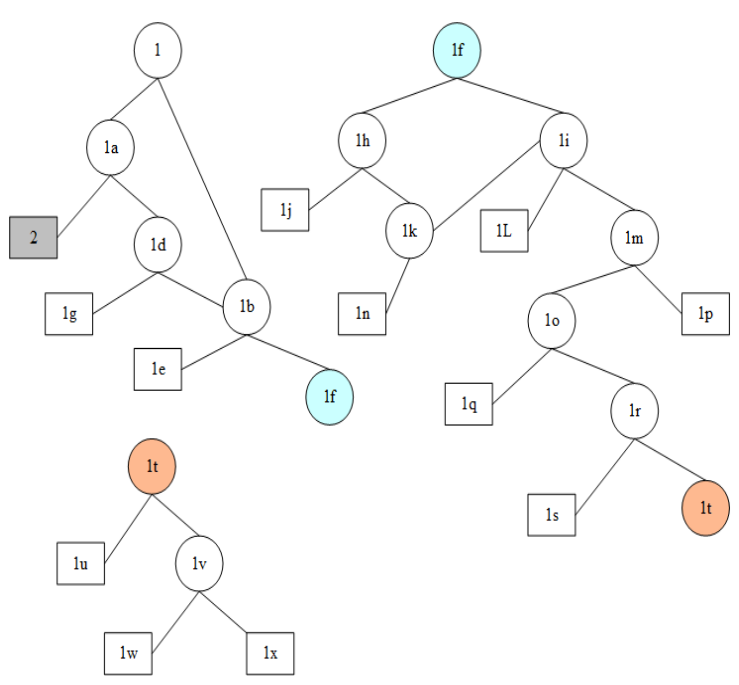

Gambar 3. Penelusuran node Solusi masalah tidur pada bayi

Pada setiap ujung node berisi solusi yang tepat berdasarkan jalur pada node tersebut, akan tetapi tidak semua ujung node merupakan solusi terakhir. Solusi yang di berikan pada setiap ujung node pada Gambar 3, dapat menjadi acuan untuk penelusuran solusi terbaik pada pohon masalah lainnya. Seperti pada jalur 1-1a-2 pada Gambar 3, solusi yang 
diberikan merupakan penelusuran lebih rinci ke pohon masalah lainnya untuk memperoleh solusi yang lebih baik. Pada beberapa masalah tertentu penelusuran akan membutuhkan waktu yang cukup lama apabila solusi yang diberikan pada ujung node merupakan acuan ke pohon lainnya untuk mengetahui masalah lebih spesifik hingga menemukan node solusi akhir.

Untuk memperoleh solusi atau mengetahui penyebab masalah yang terjadi, maka pengguna terlebih dahulu menjawab beberapa pertanyaan untuk memastikan gejala yang dialami oleh bayi atau anak untuk memberikan solusi terbaik berdasarkan algoritma best first search.

Berikut ini contoh hasil implementasi berdasarkan alur pencarian solusi 1-1b-1e seperti pada Gambar 3.

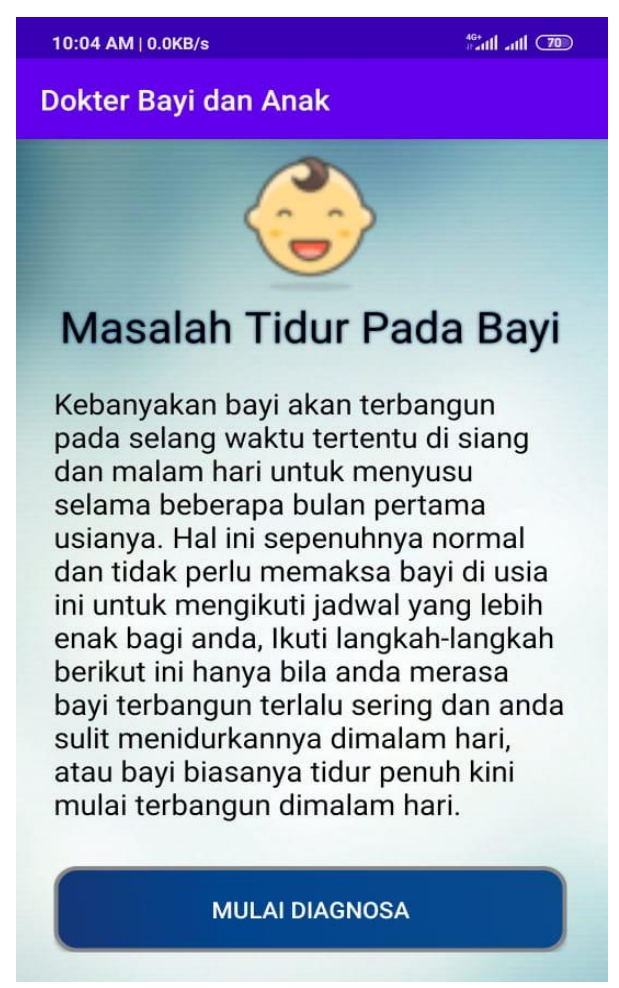

Gambar 4. Informasi Awal sebelum Mememulai Diagnosa

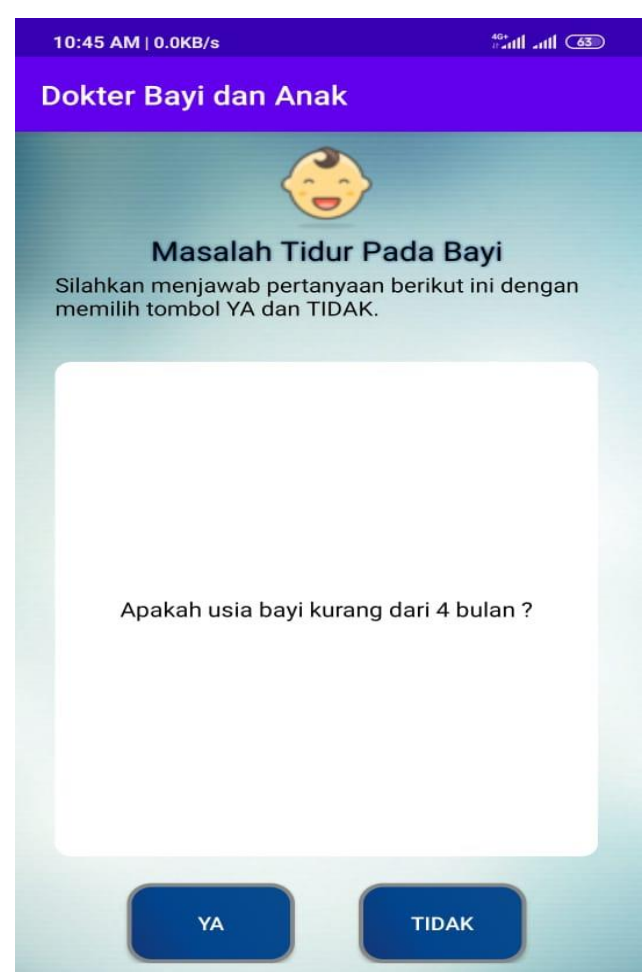

Gambar 5. Pertanyaan Node 1

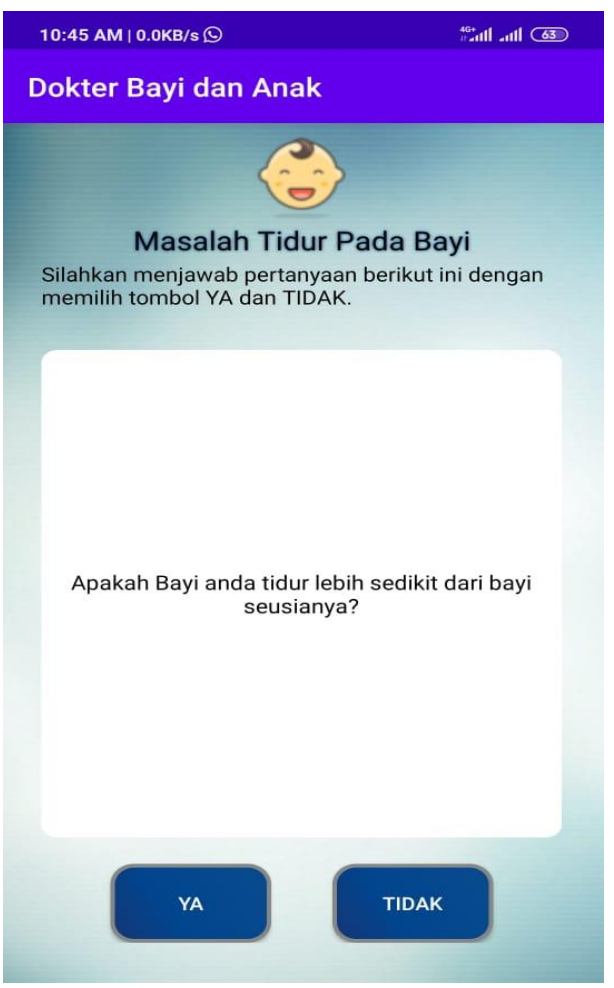

Gambar 6. Pertanyaan Node 1b 


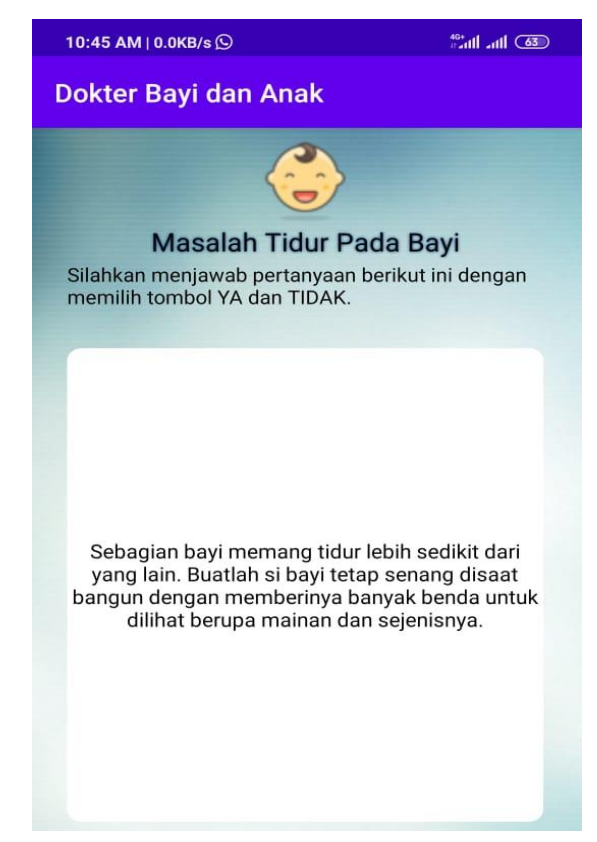

Gambar 7. Node 1e (solusi)

\section{SIMPULAN DAN SARAN}

Implementasi algoritma Best First Search dapat membantu menemukan solusi yang tepat dalam suatu permasalahan yang terdiri dari node node yang membentuk pohon pencarian.

Durasi waktu yang dibutuhkan untuk memproses pencarian setiap node bergantung pada banyaknya node yang dilalui untuk mendapatkan solusi. Pada beberapa masalah membutuhkan waktu yang cukup lama dikarenakan pada beberapa node solusi bisa menjadi node yang baru untuk permasalahan yang lebih spesifik seperti pada 1-1a-2, dimana solusi pada node 2 merupakan acuan pada pohon keputusan yang baru.

\section{UCAPAN TERIMA KASIH}

Penelitian ini disponsori oleh Kementrian Riset dan Teknologi Pendidikan Tinggi dalam program hibah Penelitian Dosen Pemula Tahun 2020, untuk itu peneliti mengucapkan Terima Kasih Sebesar-besarnya kepada
Kemenristek Dikti. Dan juga STMIK KHARISMA Makassar yang telah memberikan fasilitas pendukung dalam melakukan penelitian, serta para tenaga kesehatan yang telah bersedia menjadi narasumber untuk penelitian ini.

\section{DAFTAR PUSTAKA}

Al azizi, khalid mahfudh, Rafi, M., \& Fazlullah, H. (2020). Penerapan Algoritma Best first search Pada Sistem Pakar Untuk Menentukan Penyakit Pepaya Berbasis Web. InfoTekJar: Jurnal Nasional Informatika Dan Teknologi Jaringan, 2(Vol 4, No 2 (2020): InfoTekJar Maret: in PRESS), 0-4. Retrieved from

https://jurnal.uisu.ac.id/index.php/inf otekjar/article/view/2344

Apriandi, R., Rismawan, T., \& Midyanti, D. M. (2018). Penerapan Metode Best first search (BFS) Untuk Pencarian Lokasi SPBU Terdekat Menggunakan Arduino Berbasis Android. Jurnal Coding, Sistem Komputer Untan, 06(1), 1-11.

Hutahaean, H. D. (2018). Penerapan Metode Best first search Pada Permainan Tic Tac Toe. Journal of Computer Networks, Architecture and High Performance Computing, 1(1), 10-15.

https://doi.org/10.47709/cnapc.v1i1.3

Poetra, D. A., Sujito, \& Syaifulloh, A. (2017). Penerapan Algoritma Best first search untuk Pemilihan Angkutan Kota Malang. In Seminar Nasional Sistem Informasi 2017 (pp. 
809-817). Malang, Indonesia: UNMER Malang.

Santi. (2015). Penerapan Algoritma Best first search (BFS) dalam Pencarian Lokasi Apotek K-24 Berbasis Android di Kota Makassar. SNIf, 288-291.

Smith, T., \& Davidson, S. (2009). Masalah Pada Bayi dan Anak. In H. M. Soekardjo (Ed.), Panduan Kesehatan
Keluarga Dokter di Rumah Anda (4th ed., Vol. 4, pp. 50-65). Jakarta: Dian Rakyat.

Supartini, W., \& Hindarto, H. (2016). Sistem Pakar Berbasis Web Dengan Metode Forward Chaining Dalam Mendiagnosa Dini Penyakit Tuberkulosis Di Jawa Timur. Kinetik, 1(3), 147. https://doi.org/10.22219/kinetik.v1i3. 123 